\title{
Sanitation By-Products Used for Lettuce (Lactuca sativa L.) Production: Quantitative Microbial Risk Assessment
}

\author{
Drissa Sangare ${ }^{*}$, Loukou Alexis Brou ${ }^{2}$, Mariam Sou/Dakoure ${ }^{3}$, Nowaki Hijikata ${ }^{4}$, \\ Hamma Yacouba ${ }^{3}$, Lacina Coulibaly ${ }^{1}$, Naoyuki Funamizu ${ }^{4}$ \\ ${ }^{1}$ Agronomic, Forestry and Environmental Engineering Department, University of Man, Man, Côte d'Ivoire \\ ${ }^{2}$ Laboratory of Geosciences and Environment, University Jean Lorougnon Guede, Daloa, Côte d'Ivoire \\ ${ }^{3}$ Water and Sanitation Department, International Institute for Water and Environmental Engineering (2iE), Ouagadougou, \\ Burkina Faso \\ ${ }^{4}$ Division of Environmental Engineering, Faculty of Engineering, Hokkaido University, Kita-ku, Sapporo, Hokkaido, Japan \\ Email: ^dsangare2012@gmail.com, *drissa.sangare@univ-man.edu.ci
}

How to cite this paper: Sangare, D., Brou, L. A., Sou/Dakoure, M., Hijikata, N., Yacouba, H., Coulibaly, L., \& Funamizu, N. (2021). Sanitation By-Products Used for Lettuce (Lactuca sativa L.) Production: Quantitative Microbial Risk Assessment. Journal of Geoscience and Environment Protection, 9, 47-61.

https://doi.org/10.4236/gep.2021.910004

Received: August 28, 2021

Accepted: October 17, 2021

Published: October 20, 2021

Copyright $\odot 2021$ by author(s) and Scientific Research Publishing Inc. This work is licensed under the Creative Commons Attribution International License (CC BY 4.0).

http://creativecommons.org/licenses/by/4.0/

\begin{abstract}
Sanitation by-products (i.e. greywater, human urine and toilet compost) reuse for agriculture presents an opportunity to enhance food security while overcoming water scarcity and fertilizers issues in developing countries. However, the risks to health from farmers and consumers' exposure to pathogenic micro-organisms persistent in sanitation by-products has hindered their popularity in these regions. This study was conducted to apply a quantitative microbial risk assessment to estimate the annual risk probability of Salmonella infection associated with these sanitation by-products reuse for lettuce production and explore options for health risk reduction. Risk was performed a Monte Carlo simulation for farmers and consumers. The exposure routes were contaminated soil ingestion, urine/greywater/compost ingestion and lettuce consumption without washing. Results showed that the annual infection risks of Salmonella through ingestion contaminated soil associated with urine and compost were typical scenario: $9.04 \times 10^{-1}$ per-person-per-year (pppy) and $2.97 \times 10^{-3}$ pppy, respectively, are higher than the WHO benchmark $(\leq 1.0 \times$ $10^{-6}$ pppy). Conversely, those contaminated from greywater were $6.83 \times 10^{-6}$ pppy are meet the WHO benchmark. On the other hand, annual risks through lettuce consumption fertilized with urine $\left(1.20 \times 10^{-7} \mathrm{pppy}\right)$ were less than the risks from compost $\left(6.20 \times 10^{-3}\right.$ pppy $)$ and greywater $\left(7.76 \times 10^{-4}\right.$ pppy). Moreover, the annual risks of infection from greywater ingestion $\left(1.77 \times 10^{-1}\right.$ pppy) exhibits a much higher risk than that urine ingestion $\left(6.20 \times 10^{-3} \mathrm{pp}\right.$ py) approximately two orders of magnitude, and which are higher than the WHO tolerable limit of risk. The risk assessment outcomes of using sanita-
\end{abstract}


tion by-products to lettuce production should be promoted with proper awareness of the risk by farmers and consumers.

\section{Keywords}

Greywater, QMRA, Salmonella, Toilet Compost, Urine

\section{Introduction}

Sanitation by-products (i.e. greywater, human urine, and toilet compost) have been recognized as potential resources for agriculture as nutrients and water irrigation. These innovative approaches are therefore needed to attain both water and food security, particularly in sub-Saharan Africa. In fact, the reuse of sanitation by-products for agriculture would be an attractive option for small scale farmers in poor regions, who suffer from limited irrigation resources and poor access to chemical fertilizers. Among these resources, greywater is defined as wastewater generated from domestic activities such as dish washing, laundry and bathing, in contrast to black water, which is a mixing of feces, urine, and flush (Wiel-Shafran et al., 2006). Irrigation with greywater increases crop production and biomass productivity because it provides a valuable source of nutrients (Sangare et al., 2018), and also reduces potable water use by up to $50 \%$ (Al-Hamaiedeh \& Bino, 2010), while protecting the surrounding environment. On the other hand, human excreta (i.e. human urine and toilet compost) are among natural fertilizers, which raise interest due to their double advantages to combine sanitation, such as improve access to clean water, basic sanitation and nutrient recovery for agriculture (Sangare et al., 2015; Jamal \& Fawad, 2019). The chemical composition of urine is in ionic form and its plant availability compares with chemical fertilizer. Besides, nutrient recovery and recycling from diverted human urine can be seen as a synergistic and circular solution to the issues of sanitation, hygiene, water, and food security (Alemayehu et al., 2020). Treated urine can normally be used without crop restriction, due to the low degree of fecal contamination (WHO, 2006). Human feces or compost which contains also the precious nutrients can be reused as anthropogenic fertilizer, through proper collection, treatment, and sanitation processes (Werner et al., 2009). Furthermore, the decline in crop production due to loss of soil organic component, erosion, and nutrient runoff has generated interest in the recycling of fecal sludge compost into soil nutrients. Overall, it has been reported by many researchers that human excreta or/and fecal sludge compost can be used as organic fertilizers for growing crops and improve soil structure (Jamal \& Fawad, 2019), while reducing the sanitation problem caused by the indiscriminate disposal of fecal sludge into the environment (Appiah-Effah et al., 2015).

Despite many advantages of sanitation by-products as water irrigation and biofertilizers, their health implications are of paramount concern. Indeed, though 
a very good source of organic fertilizer, wastewater is also a very good channel for spreading pathogens, which are simply microorganisms that can infect a host and cause disease (WHO, 2006). The reuse of untreated greywater does risks to crops, soil, and public health (farmers and consumers), which include the potential accumulation of organic chemicals and pathogens in the soil and/or in plants (Maiga et al., 2018; Somda et al., 2019). In their studies, Shi et al. (2018) have shown that the annual infection risks and disease burdens of untreated greywater, especially kitchen greywater was not suitable for food-crop irrigation $(4.9 \times$ $10^{-6}$ per-person-per-year (pppy); $4.3 \times 10^{-10}$ disability-adjusted life years (DALYs) pppy) based on WHO disease burden ( $\leq 10^{-6}$ DALYs pppy) benchmarks. On the other hand, fecal matters contain a wide range of pathogenic bacteria, parasites and viruses likely to remain in toilet compost and then contaminate workers and consumers (Heinonen-Tanski \& Wijk-Sijbesma, 2005). Human exposure occurs if people come into contact with the feces or accidentally ingest the material during tank emptying and during soil amendment. Schönning et al. (2007) reported that farmers can accidentally ingest $100 \mathrm{mg}$ of compost each time they plow agricultural plots, and the annual risk of infection by Ascaris was slightly above $10^{-4}$ pppy. Agricultural workers are most at risk of parasitic infections due to the long survival of protozoa and roundworms in the compost (Carr, 2005). Contrary to feces, the potential pathogen content is low in human urine. However, the reuse non-treated urines as fertilizer in agriculture can lead to the transmission of pathogens, particularly to agricultural workers (Heinonen-Tanski et al., 2007; Tagro, 2012). The major risks would be expected to relate to the potential degree of fecal cross-contamination and reuse practices. Agricultural reuse of raw or partially treated greywater and human excreta (i.e. human urine and toilet compost), may cause any cause epidemiological problems among farm workers and consumers (WHO, 2006). However, less attention has been directed towards the risk to farmers and consumers exposed to sanitation by-products (i.e. greywater, human urine and toilet compost) reused for vegetable production in rural areas of Sahelian regions located in low income countries. For this purpose, the overall aim of this study was carried the quantitative microbial risk assessment (QMRA) of Salmonella risks infections using direct use of sanitation by-products (i.e. greywater, urine and toilet compost) for lettuce (Lactuca sativa L.) crops growing, and explore options for health risk reduction. The specific objectives were to estimate the annual probabilities infection risks due to 1) untreated greywater reuse, 2) human urine reuse, 3) toilet compost reuse, and 4) compare the annual probabilities infection risks associated these sanitation by-products following the differents exposure routes.

\section{Material and Methods}

\subsection{Experiment Design and Plant Material}

Experiments were performed at a test site located within the Kamboinsin cam- 
pus of the International Institute for Water and Environmental Engineering (2iE) $\left(12^{\circ} 27^{\prime} 40.6^{\prime \prime} \mathrm{N}, 01^{\circ} 32^{\prime} 56.0^{\prime \prime} \mathrm{W}\right)$ Ouagadougou, Burkina Faso, which has Sudano-Sahelian climate conditions with a long dry season (October-May) and a short rainy season (June-September). The experimental design was randomized complete blocks with three (3) treatments replicated three (3) times. The different treatments were: 1) Untreated Greywater (GW), 2) Toilet Compost + Tap Water (TC + TW), 3) Human Urine + Tap Water (HU + TW). At least nine (9) cultivation blocks for the experiment were used during a round fifty (50) days treatment. The Lettuce (Lactuca sativa L.) plant was chosen for this study because it is the representative food crop and is a common plant for home production. Besides, the lettuce has a short life cycle and its sensitivity to environmental conditions (Castillo et al., 2000), and particularly contamination, probably as a result of increased surface area of leaves exposed to polluted irrigation water and soil (Ceuppens et al., 2014). Lettuce, one of the most consumed leafy vegetables in the world, is frequently implicated with foodborne disease outbreaks (De Oliveira Elias et al., 2019).

\subsection{Microbial Analysis}

The sanitation by-products samples (i.e. greywater, urine and compost) were analyzed for detection of Salmonella spp.

\subsubsection{Toilet Compost and Soil Microbiological Analysis}

Toilet compost samples or soil samples $25 \mathrm{~g}$ (w/v) were homogenized in $225 \mathrm{~mL}$ of buffer phosphate water and a 10-fold dilution series was performed in maximum recovery diluents (ringer solution). $10 \mathrm{~mL}$ of Rappaport Vassiliadis media were added in test tubes of different dilutions $\left(10^{0}\right.$ to $\left.10^{-6}\right)$ where three to five repetitions are made per dilution and $1 \mathrm{~mL}$ of sample is added in the test tubes. Then, the test tubes were placed inside a $37^{\circ} \mathrm{C}$ in incubator during $24 \mathrm{hrs}$ for reading before to sow in ChromAgar media on petri plate and then to incubate at $37^{\circ} \mathrm{C}$ during $24 \mathrm{hrs}$. The use of the Mac Grady statistical table allowed to know the Most Probable Number per gram (MNP/g).

\subsubsection{Greywater and Human Urine Microbiological Analysis}

The same method as previously was used, but in this case, the dilution is made directly without homogenization with buffer phosphate water. And, the use of the Mac Grady statistical table allowed to know the Most Probable Number per Liter (MNP/L).

\subsubsection{Lettuce Leaves Microbiological Analysis}

Salmonella counts were estimated in about $10 \mathrm{~g}$ of lettuce samples, which was weighed into $90 \mathrm{~mL}$ of a solution of $\mathrm{NaCl}$ with $1 \mathrm{~N}$ into separate, sterile bottles and homogenized for $15 \mathrm{~min}$. The homogenised supernatant of $10^{-1}$, and appropriate serial dilutions of the suspension were spread-plated on a suitable solid media. A suspension of $0.1 \mathrm{~mL}$ of the stock solution and of each of the dilutions were inoculated at $37^{\circ} \mathrm{C}$ for $24 \mathrm{hrs}$. 


\subsection{Quantitative Microbial Risk Assessment (QMRA) Model}

Quantitative microbial risk assessment (QMRA) is a process employed to estimate adverse health effects resulting from exposure to micro-organisms associated with specific scenarios (Hamilton et al., 2006). This procedure allows the estimation of the infection or illness rates based on the pathogen densities. It involves four steps: 1) hazard identification, 2) exposure assessment, 3) dose-response assessment, and 4) risk characterization.

\subsubsection{Hazard Identification}

Salmonella spp. was identified as potential sources of hazard in edible crop fertilization/irrigation with wastewater (i.e. human excreta). Salmonella is found in large numbers in sewage and, it is enteric pathogen which is one of the leading causes of intestinal illnesses, such as gastroenteritis, bacteremia, and typhoid fever (Levantesi et al., 2012). Besides, Salmonella infection represents a considerable burden in both developing and developed countries, according to Majowicz et al. (2010). They showed also that Salmonella spp. in lettuce had a mean prevalence of 0.028 (95\% CI: $0.014-0.042$ ) in developed countries and 0.064 (0.041 - 0.087) in developing countries, with reports varying from 0.001 in Japan to 0.5 in Burkina Faso. The QMRA scenario included surface irrigation, consumption of raw crops, and 1-day withholding period before harvest. Lettuce is consumed uncooked and it retains a relatively large volume of water on the surface of the plant, thus conferring greater potential for transfer of pathogens from irrigation water (Barker et al., 2013). Indeed, lettuce showed the highest risk of Salmonella infection in all scenarios considered, according to probabilistic QMRA in direct agricultural reuse of treated wastewater (Amha et al., 2015).

\subsubsection{Exposure Assessment}

The model took into consideration two types of population: farm workers and consumers. Farm workers without proper protection (i.e. gloves, shoes) may accidentally ingest sanitation by-products, and soil contaminated during fertilizing lettuce crop. On the other hand, the consumers can eat lettuce fertilized with sanitation by-products without washing it. The volume of greywater, compost and urine ingested during each type of exposure was summarized in Table 1. The lettuce crop is practiced only during the dry season, which lasts nine (9) months (270 days) in Burkina Faso. The cultural cycle of lettuce plant for this experiment was around fifty (50) days, which is corresponded five (5) lettuce crop cycles per year. During one (1) crop cycle, lettuce plants were fertigated with human urine three (3) times, which corresponded frequency exposed is fifteen (15) events per year for farm workers. Farm worker may accidentally inhalation of aerosols $(0.43 \mathrm{~mL}$ urine) created when applying urine or by contaminated hand mouth contact. Furthermore, toilet compost was applied one (1) time during lettuce crop cycle. Thereby, farm workers could be exposed five (5) events per year at toilet compost. The farm worker can ingest $100 \mathrm{mg}$ of compost accidentally per exposure, when they spread it in the field (Schönning et al., 2007). For irrigation, the volume of greywater ingested involuntarily was assumed to be 
Table 1. Potential case and practice scenarios of exposure to sanitation by-products (i.e. greywater, compost and urine), soil contaminated, and consumed lettuce.

\begin{tabular}{|c|c|c|c|c|}
\hline $\begin{array}{l}\text { Groupes } \\
\text { Exposed }\end{array}$ & Matrix & Exposure routes & $\begin{array}{l}\text { Volume } \\
\text { ingested }\end{array}$ & $\begin{array}{c}\text { Frequency } \\
\text { exposed }\end{array}$ \\
\hline \multirow{4}{*}{ Farmers } & Greywater & $\begin{array}{l}\text { Ingestion of greywater from the } \\
\text { irrigation system (watering can) } \\
\text { Accidental ingestion }\end{array}$ & $1-2 \mathrm{~mL}^{\mathrm{a}}$ & 275 \\
\hline & Compost & $\begin{array}{l}\text { Handle without personal } \\
\text { protective equipment (PPE) } \\
\text { before to spread compost }\end{array}$ & $10-100 \mathrm{mg}^{\mathrm{b}}$ & 5 \\
\hline & Urine & $\begin{array}{l}\text { Inhalation of aerosols while } \\
\text { fertilizing crops with urine }\end{array}$ & $0.43 \mathrm{~mL}$ & 15 \\
\hline & Soil & $\begin{array}{l}\text { Ingestion of soil contaminated with } \\
\text { compost, urine and greywater }\end{array}$ & $10-100 \mathrm{mg}^{\mathrm{c}}$ & 20 \\
\hline Consumers & Lettuce & $\begin{array}{l}\text { Consumers can eat lettuce } \\
\text { without washing it }\end{array}$ & $10.8 \mathrm{~mL} / 100 \mathrm{~g}^{\mathrm{d}}$ & 52 \\
\hline
\end{tabular}

a. (Ackerson \& Awuah, 2012); b. (Schönning et al., 2007); c. (Haas et al., 1999); d. (Shuval et al., 1997).

$1-2 \mathrm{~mL}$ at 275 days' exposure per year for farmers (Ackerson \& Awuah, 2012). On the other hand, farmers could have ingested soil contaminated with compost, urine during labor intensive (i.e. planting, weeding) in field. These activities can be occurred four (4) times per lettuce crop cycle, which corresponded twenty (20) days exposure per year. The volume of soil contaminated per exposure ingested accidentally by farmers was estimated from 10 to $100 \mathrm{mg}$ (Haas et al., 1999; WHO, 2006).

Consumers don't wash and rinse the lettuce leaves with clean water prior to consumption. The amount of lettuce consumed per person a single week was taken as $100 \mathrm{~g}$ in developing country (Ackerson \& Awuah, 2012). Thus, consumer can be exposed 52 events per year.

\subsubsection{Dose-Response Assessment}

The Beta-Poisson model was used to model the dose response of Salmonella caused infections (Haas et al., 1999). The microbial risk of Salmonella was calculated by:

Exponential dose-response model (Equation (1)):

$$
P_{\text {inf }}(r, d)=1-\exp (-r d)
$$

Beta-Poisson model (Equation (2)):

$$
P_{\text {inf }}\left(d, \alpha, N_{50}\right)=1-\left[1+d / N_{50}\left(2^{1 / \alpha}-1\right)\right]^{-\alpha}
$$

in which $P_{\text {inf }}$ is the probability of infection from a single exposure per day (based on $d$ : Mean dose of pathogens ingested, and $r$ is the probability of one organism initiating an infection, $N_{50}$ is the median infective dose (number of pathogens), and $\alpha$ is a shape factor (Pathogens constants)). The dose-response parameters for exponential and Beta-Poisson models from Salmonella ingestion were summarized in Table 2. 
Table 2. Dose-response parameters for exponential and Beta-Poisson models from Salmonella ingestion.

\begin{tabular}{cccc}
\hline & exponential & \multicolumn{2}{c}{ Beta-Poisson } \\
\cline { 2 - 4 } & $\mathrm{r}$ & $\alpha$ & $\mathrm{N}_{50}$ \\
\hline Salmonella & $0.00752^{\mathrm{a}}$ & $0.313^{\mathrm{b}}$ & $23.600^{\mathrm{b}}$ \\
\hline
\end{tabular}

a. (Metcalf \& Eddy, 2007); b. (Schönning et al., 2007).

\subsubsection{Risk Characterization}

The final step in this risk assessment approach is to determine the magnitude of the risk by integrating information from the problem formulation, exposure assessment, and health effect assessment. The computed health risk was based on the cumulative, the volume of accidental ingestion of toilet compost, human urine and soil contaminated for the farm workers during operational activities, and the volume of consumed lettuce for consumers. The annual probability of infection risk was determined with Equation (3) (Haas et al., 1999):

$$
P_{y r}=1-\left(1-P_{\text {inf }}\right)^{n}=n \times P_{\text {inf }}
$$

in which $P_{y r}$ is the probability of infection from $n$ exposure events per year. To account for variability and uncertainty in the parameters, different parts of the model were subjected to Monte-Carlo simulation of 100,000 iterations in R software version 3.2.5. Indeed, each scenario ran 100,000 times, in which the frequency of volume and events were randomly changed according to the corresponding distribution, for each run. The Salmonella load was also modified between the limits appear in Table 2. The output of the model generated 100,000 pathogen concentrations compatible with annual probabilities of infection, for each scenario and the output data was statistically analyzed. The annual probability of infection was determined for each exposure scenario, and the risk was characterized as above or below the WHO (2006) benchmark tolerable risk $(\leq 1$ $\times 10^{-6}$ pppy).

\section{Results and Discussion}

\subsection{Microbial Quality of Greywater and Human Excreta}

Table 3 summarizes the mean and standard deviation of Salmonella loads for untreated greywater, human excreta (urine and toilet compost), and soil before cultivation. The present study confirms the detection of pathogens in all the selected sampling matrix, excepted soil. The Salmonella loads were 156.63 and 3.95 $\log _{10} \mathrm{MPN} / 100 \mathrm{~mL}$, and $3.31 \log _{10} \mathrm{MPN} / \mathrm{gDW}$ for greywater, human urine, and toilet compost, respectively. In terms of Salmonella loads, the greywater is much more polluted than urine, and toilet compost. This fecal contamination of greywater come from the activities such as washing fecal contaminated diapers, childcare, anal cleansing and showering (Morel \& Diener, 2006). On the other hand, the urine fraction is normally free from pathogens when leaving the body, but in many systems it can be contaminated by feces. 
Table 3. Salmonella loads in sanitation by-products and soil before cultivation.

\begin{tabular}{cc}
\hline Matrix & Salmonella spp. loads \\
\hline Greywater & $156.63 \pm 199.80 \log _{10} \mathrm{MPN} / 100 \mathrm{~mL}$ \\
Human urine & $156.63 \pm 199.80 \log _{10} \mathrm{MPN} / 100 \mathrm{~mL}$ \\
Toilet compost & $156.63 \pm 199.80 \log _{10} \mathrm{MPN} / 100 \mathrm{~mL}$ \\
Soil & n.d. \\
\hline
\end{tabular}

n.d. no detected.

\subsection{Annual Probabilities Infection Risks from Untreated Greywater Reuse}

Table 4 presents the annual infection risks $\left(P_{y r}\right)$ that were estimated under the scenarios where farmers and consumers were exposed to Salmonella from untreated greywater reuse. The annual infection risks of Salmonella were typical scenario: $6.83 \times 10^{-6}$ pppy and worst-case scenario: $8.89 \times 10^{-6}$ pppy for farmers ingesting accidentally 10 to $100 \mathrm{mg}$ contaminated soil, which are meet the WHO (2006) annual infection benchmark ( $\leq 1.0 \times 10^{-6}$ pppy). Conversely, the annual infection risks for those ingesting 1 to $2 \mathrm{~mL}$ irrigation greywater (typical scenario: $1.77 \times 10^{-1}$ pppy and worst-case scenario: $1.91 \times 10^{-1}$ pppy) are significantly higher than the WHO benchmark. The higher risk is observed in lettuce irrigation due to the higher possibility of direct accidental ingestion. In this scenario, it was predictable that the annual risks infection was higher than the recommended benchmark of infection of $1.0 \times 10^{-6}$ by the WHO standard, because farmers in developing countries have direct contact with the wastewater as a result of the non-use of adapted equipments, such as mask, face shields, shoes and gloves for irrigation (Sampson et al., 2017). Thus, Petterson \& Ashbolt (2016) reported that the exposure during the reuse contaminated water have the source of several disease outbreaks. On the other hand, Salmonella annual infection risks from using untreated greywater with lettuce consumption were typical scenario: $7.76 \times 10^{-4}$ pppy and worst-case scenario: $9.42 \times 10^{-4}$ pppy, pose also a threat that is far beyond the threshold recommended by the WHO (2006). The annual risk probability of Salmonella infection was similar to those obtained by Ezzat (2019) for consumers, and exceeded the target tolerable risk $\left(7.7 \times 10^{-4}\right.$ pppy) for lettuce irrigated from unofficial wastewater. These high annual risks could due the time elapsed between last irrigation event and harvest (1-day withholding period), as well as irrigation method (Abel \& Taylor, 2018). In general, the annual risks infection associated with pathogens from irrigation wastewater is variable depending on crop type, irrigation type, and days between last irrigation event and harvest, according to Stine et al. (2005). In their studies, they showed that Salmonella annual risk of infection was to range from $1.5 \times$ $10^{-2}$ to $7.2 \times 10^{-6}$ pppy, depending on whether the last irrigation event was 1 or 14 days before harvest. The annual risk infection is high maximum after harvested the day after the last irrigation event. Additionally, highest levels of bacterial contamination recorded to lettuce are probably as a result of increased 
Table 4. Annual probabilities of Salmonella risks infection from from greywater reuse.

\begin{tabular}{ccc}
\hline Risks Scenario & $\begin{array}{c}\text { Typical Scenario (pppy) } \\
\left(50^{\text {th }} \text { percentile }\right)\end{array}$ & $\begin{array}{c}\text { Worst-case Scenario (pppy) } \\
\left(95^{\text {th }} \text { percentile }\right)\end{array}$ \\
\hline Soil ingestion $(\mathrm{n}=20$ days $)$ & $6.83 \times 10^{-6}$ & $8.89 \times 10^{-6}$ \\
Greywater ingestion $(\mathrm{n}=275$ days $)$ & $1.77 \times 10^{-1}$ & $1.91 \times 10^{-1}$ \\
Lettuce Consumption $(\mathrm{n}=52$ days $)$ & $7.76 \times 10^{-4}$ & $9.42 \times 10^{-4}$ \\
\hline
\end{tabular}

surface area of leaves exposed to polluted irrigation water and soil (Ceuppens et al., 2014). Moreover, several studies reported that the highest risk of infection for lettuce than the raw consumption of other vegetables (Amha et al., 2015; Ezzat, 2019). In addition to the use of untreated greywater and the consumption of lettuce irrigated with untreated greywater, the contamination of soils has been shown to be a low risk factor in this current scenario. On the other hand, the higher risk is observed in greywater ingestion due to the higher possibility of direct accidental ingestion associated crop irrigation. The risk variation from greywater ingestion and lettuce consumption is due to the number of days for exposure. For lettuce consumption, the exposure time is limited to 52 days (2 months), while exposure of greywater ingestion is 275 days ( 9 months). These results suggest the need for wastewater treatment plants, raising awareness in the population (i.e. farmer and consumer), using the untreated greywater and/or wastewater for irrigation. On the other hand, the use protective gear (masks, gloves, coats) could be reduced exposure to pathogenic microorganisms (WHO, 2006). The risks can be also reduced through postharvest practices such as washing and disinfection for raw consumption (i.e. lettuce). In general, these measures will reduce the probability of risks infection for any reuse in the current scenario.

\subsection{Annual Probabilities Infection Risks from Toilet Compost Reuse}

The annual risks infection of Salmonella caused by involuntary ingestion for farmers working in fields where toilet compost is used as a fertilizer and end-consumers of lettuces grown in fields fertilized with toilet compost are illustrated in Table 5. The results showed that the annual infection risks of Salmonella (typical scenario: $2.97 \times 10^{-3}$ pppy and worst-case scenario: $3.87 \times 10^{-3} \mathrm{pppy}$ ) for worker farm ingesting involuntary soil contaminated with toilet compost are significantly higher than the tolerable limit of risk defined by the WHO (2006) as $10^{-6}$ pppy. For consumers, the annual risks infection of Salmonella (typical scenario: $6.20 \times$ $10^{-3}$ pppy and worst-case scenario: $7.24 \times 10^{-3} \mathrm{pppy}$ ), associated the lettuce consumption amended with toilet compost were all far exceed the benchmark. These results showed that the annual risks of infection from farming activities and lettuce consumption were higher than the tolerable limit of risk defined by the World Health Organization as $1 \times 10^{-6}$ pppy (WHO, 2006). The infection risks from soil ingestion and lettuce consumption are very close to one another 
Table 5. Annual probabilities of Salmonella risks infection associated with toilet compost reuse.

\begin{tabular}{ccc}
\hline Risks Scenario & $\begin{array}{c}\text { Typical Scenario (pppy) } \\
\left(50^{\text {th }} \text { percentile }\right)\end{array}$ & $\begin{array}{c}\text { Worst-case Scenario (pppy) } \\
\left(95^{\text {th }} \text { percentile }\right)\end{array}$ \\
\hline Soil ingestion $(\mathrm{n}=20$ days $)$ & $0.97 \times 10^{-3}$ & $3.87 \times 10^{-3}$ \\
Lettuce Consumption $(\mathrm{n}=52$ days $)$ & $6.20 \times 10^{-3}$ & $7.24 \times 10^{-3}$ \\
\hline
\end{tabular}

for the toilet compost reuse. The mitigation measures could be adopted, such as improved composting process (Urea treatment), limitation in the use of toilet compost (application control), use of personal protection equipment (mask, face shields, shoes, gloves) and behavioral change for farmers (personal hygiene) and consumers (improve washing of produce) along the toilet compost-reuse chain (Strunz et al., 2014; Sossou et al., 2016; Butte et al., 2021). In this order, Butte et al. (2021) have reported that these possible mitigation strategies for workers and farmers showed a reduction in monthly risk of $30 \%-70 \%$ from fecal sludge reuse.

\subsection{Annual Probabilities Infection Risks from Human Urine}

The annual risks infection of Salmonella caused by involuntary ingestion for farmers working in fields where human urine is used as a fertilizer and end-consumers of lettuces grown in fields fertilized with human urine are mentioned in Table 6. The annual risks infection of farmer exposure to Salmonella for soil contaminated with urine (typical scenario: $9.04 \times 10^{-1}$ pppy and worst-case scenario: 9.55 $\times 10^{-1}$ pppy), and inhalation of aerosols while fertilizing crops with urine (typical scenario: $6.00 \times 10^{-3}$ pppy and worst-case scenario: $8.48 \times 10^{-3}$ pppy), were higher than the threshold of $1 \times 10^{-6}$ WHO benchmark. As mentioned previous scenarios, protective measures were rarely used during exposure to urine reuse; this may contribute to higher risks for workers in contact with urine. In contrast to farmers, the results present the low annual risks infection of consumer exposure to Salmonella (typical scenario: $1.20 \times 10^{-7}$ pppy and worst-case scenario: $1.30 \times 10^{-7}$ pppy), and which are below the threshold recommended by WHO (2006). Similarly, Höglund et al. (2002) revealed that the ingestion of crops contaminated with urine resulted in risks of $<1 \times 10^{-5}$ pppy after a 3-week $\left(<1 \times 10^{-7}\right.$ pppy after 4 weeks) withholding period between fertilizing and harvesting. Indeed, for production and raw consumption of crops, urine has to be stored for at least six months $\left(\mathrm{T}>20^{\circ} \mathrm{C}\right)$ before application to ensure a high level of pathogen inactivation, as outlined by WHO (2016) guidelines. On the other hand, Sangare et al. (2021) showed also that after 3 days of exposure to sunlight (SODIS method) urine collected via toilet becomes bacteriologically (Salmonella, E. coli) sanitized, and can therefore be used in agriculture. In current scenario, lower annual risk infection is observed in lettuce consumption compared the both others routes exposure (soil ingestion and urine ingestion). The risks variation from lettuce consumption and both routes exposure could be due the urine is applied from prior to sowing, up until two-thirds of the period between sowing 
Table 6. Annual probabilities of Salmonella risks infection from human urine reuse.

\begin{tabular}{ccc}
\hline Risks Scenario & $\begin{array}{c}\text { Typical Scenario (pppy) } \\
\left(50^{\text {th }} \text { percentile }\right)\end{array}$ & $\begin{array}{c}\text { Worst-case Scenario (pppy) } \\
\left(95^{\text {th }} \text { percentile }\right)\end{array}$ \\
\hline Soil ingestion $(\mathrm{n}=20$ days $)$ & $9.04 \times 10^{-1}$ & $9.55 \times 10^{-1}$ \\
Urine ingestion $(\mathrm{n}=15$ days $)$ & $6.00 \times 10^{-3}$ & $8.48 \times 10^{-3}$ \\
Lettuce Consumption $(\mathrm{n}=52$ days $)$ & $1.20 \times 10^{-7}$ & $1.30 \times 10^{-7}$ \\
\hline
\end{tabular}

and harvest. The time since last urine applied and harvest could reduce the annual risks infection of eating lettuce to an acceptable level, through decay of Salmonella. Additionally, urine is not being applied on leaves or other parts of the plants, as this can cause foliar burning (Rodhe et al., 2004) and the hygiene risk through aerosols. These measures could be reduced the probability of risks infection for raw consumption, like lettuce from urine reuse. For the both routes exposure, worker farm can have used of personal protection equipment (mask, face shields, shoes, gloves) to reduce the risks infections associated.

\subsection{Comparison of Annual Probabilities Infection Risks of Salmonella Associated Sanitation By-Products}

The annual risks infection of Salmonella from three sanitation by-products (i.e. greywater, human urine and toilet compost) and different exposure routes (soil ingestion, lettuce consumption and greywater/urine ingestion) are illustrated in Figure 1. The annual infection risks of Salmonella through ingestion accidentally contaminated soil associated with urine reuse (typical scenario: $9.04 \times 10^{-1}$ pppy) are higher than those contaminated from toilet compost (typical scenario: $2.97 \times 10^{-3}$ pppy), greywater (typical scenario: $6.83 \times 10^{-6}$ pppy) and which are all exceed the WHO benchmark. On the contrary, the annual risks of Salmonella through lettuce consumption fertilized with urine (typical scenario: $1.20 \times 10^{-7}$ pppy) were less than the annual risks from toilet compost (typical scenario: 6.20 $\times 10^{-3}$ pppy) and greywater reuse (typical scenario: $7.76 \times 10^{-4}$ pppy). On the other hand, the annual risks infection from untreated greywater ingestion (1.77 $\times 10^{-1}$ pppy) exhibits much higher risk than those urine ingestion $\left(6.00 \times 10^{-3}\right.$ pppy) approximately two orders of magnitude. The risk variation from greywater ingestion could be explained by the number of days for exposure. Indeed, the exposure time is to 275 days ( 9 months) for greywater ingestion, while exposure of urine ingestion is 15 days (less of 1 month).

It clearly indicates that the annual infection risks of Salmonella through lettuce consumption fertilized with urine are significantly less than those other sanitation by-products (i.e. toilet compost and greywater). On the other hand, urine and greywater ingestion posed the greatest hazard to farmers for Salmonella infections. These could be controlled by use of personal protection equipment and treatment of the sanitation by products. Finally, the present study showed that the annual infections risks of Salmonella are higher in farm workers than consumers. 


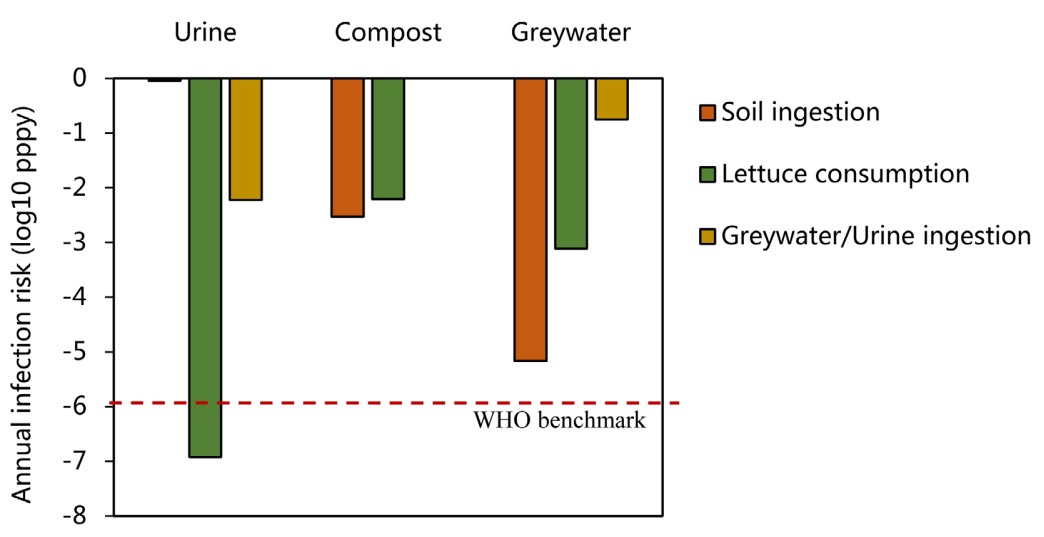

Figure 1. Comparison of annual infection risks from sanitation by-products reuse (greywater, urine and toilet compost).

\section{Conclusion}

The risk assessment outcomes of using sanitation by-products indicate that the Salmonella annual risk of farmer exposure for ingestion accidentally contaminated soil associated with urine reuse (typical scenario: $9.04 \times 10^{-1}$ pppy) and ingesting involuntary greywater (typical scenario: $1.77 \times 10^{-1}$ pppy) are significantly higher than the WHO benchmark $\left(\leq 1.0 \times 10^{-6} \mathrm{pppy}\right)$ and the others exposure routes. For the consumers' exposure, the results present the low annual risks of infection of Salmonella through lettuce consumption fertilized with urine (typical scenario: $1.20 \times 10^{-7}$ pppy), and which are below the threshold recommended by WHO. Overall, the results show the higher risks of infection in all scenarios and did not meet the threshold of $1 \times 10^{-6}$ pppy benchmark, excepted lettuce consumption fertilized with urine and ingestion of contaminated soil with greywater. The mitigation measures could be adopted, such as the use of personal protection equipment (mask, face shields, shoes, gloves) and behavioral change for farmers (personal hygiene) and consumers (improve washing of produce), and reuse sanitation by-products treated before cultivation. Further studies are necessary to perform the infection risks assessment of handling toilet compost and urine in families' pilot sites before reuse.

\section{Conflicts of Interest}

The authors declare no conflicts of interest regarding the publication of this paper.

\section{References}

Abel, N. V., \& Taylor, M. B. (2018). The Use of Quantitative Microbial Risk Assessment to Estimate the Health Risk from Viral Water Exposures in Sub-Saharan Africa: A Review. Microbial Risk Analysis, 8, 32-49. https://doi.org/10.1016/j.mran.2017.12.001

Ackerson, N. O. B., \& Awuah, E. M. (2012). Microbial Risk Assessment of Urban Agricultural Farming: A Case Study on Kwame Nkrumah University of Science and Technology Campus, Kumasi, Ghana. International Journal of Science and Technology, 1, 118-125. 
Alemayehu, Y. A., Asfaw, S. L., \& Terfie, T. A. (2020). Nutrient Recovery Options from Human Urine: A Choice for Large Scale Application. Sustainable Production and Consumption, 24, 219-231. https://doi.org/10.1016/j.spc.2020.06.016

Al-Hamaiedeh, H., \& Bino, M. (2010). Effect of Treated Greywater Reuse in Irrigation on Soil and Plants. Desalination, 256, 115-119. https://doi.org/10.1016/j.desal.2010.02.004

Amha, Y. M., Kumaraswamy, R., \& Ahmad, F. (2015). A Probabilistic QMRA of Salmonella in Direct Agricultural Reuse of Treated Municipal Wastewater. Water Science and Technology, 71, 1203-1211. https://doi.org/10.2166/wst.2015.093

Appiah-Effah, E., Nyarko, K. B., Adum, L., Antwi, E. O., \& Awuah, E. (2015). Perception of Peri-Urban Farmers on Fecal Sludge Compost and Its Utilization: A Case Study of Three Peri-Urban Communities in Ashanti Region of Ghana. Compost Science \& Utilization, 23, 267-275. https://doi.org/10.1080/1065657X.2015.1046616

Barker, S. F., O’Toole, J., Sinclair, M. I., Leder, K., Malawaraarachchi, M., \& Hamilton, A. J. (2013). A Probabilistic Model of Norovirus Disease Burden Associated with Greywater Irrigation of Home-Produced Lettuce in Melbourne, Australia. Water Research, 47, 1421-1432. https://doi.org/10.1016/j.watres.2012.12.012

Butte, G., Niwagaba, C., \& Nordin, A. (2021). Assessing the Microbial Risk of Faecal Sludge Use in Ugandan Agriculture by Comparing Field and Theoretical Model Output. Water Research, 197, Article ID: 117068. https://doi.org/10.1016/j.watres.2021.117068

Carr, R. (2005). WHO Guidelines for Safe Wastewater Use-More than Just Numbers. Irrigation and Drainage, 54, S103-S111. https://doi.org/10.1002/ird.190

Castillo, G. C., Vila, I. C., \& Neild, E. (2000). Ecotoxicity Assessment of Metals and Wastewater Using Multitrophic Assays. Environmental Toxicology, 15, 370-375. https://doi.org/10.1002/1522-7278(2000)15:5\%3C370::AID-TOX3\%3E3.0.CO;2-S

Ceuppens, S., Hessel, C. T., Rodrigues, R. Q., Bartz, S., Tondo, E. C., \& Uyttendaele, M. (2014). Microbiological Quality and Safety Assessment of Lettuce Production in Brazil. International Journal of Food Microbiology, 181, 67-76. https://doi.org/10.1016/j.ijfoodmicro.2014.04.025

De Oliveira Elias, S., Noronha, T. B., \& Tondo, E. C. (2019). Salmonella spp. and Escherichia coli O157:H7 Prevalence and Levels on Lettuce: A Systematic Review and Meta-Analysis. Food Microbiology, 84, Article ID: 103217. https://doi.org/10.1016/j.fm.2019.05.001

Ezzat, S. M. (2019). Applying Quantitative Microbial Risk Assessment Model in Developing Appropriate Standards for Irrigation Water. Integrated Environmental Assessment and Management, 16, 353-361. https://doi.org/10.1002/ieam.4232

Haas, C. N., Rose, J. B., \& Gerba, C. P. (1999). Quantitative Microbial Risk Assessment (464 pp). John Wiley \& Sons.

Hamilton, A. J., Stagnitti, F., Premier, R., Boland, A. M., \& Hale, G. (2006). Quantitative Microbial Risk Assessment Models for Consumption of Raw Vegetables Irrigated with Reclaimed Water. Applied and Environmental Microbiology, 72, 3284-3290. https://doi.org/10.1128/AEM.72.5.3284-3290.2006

Heinonen-Tanski, H. Sjöblom, A., Fabritius, H., \& Karinen, P. (2007). Pure Human Urine Is a Good Fertiliser for Cucumbers. Bioresource Technology, 98, 214-217. https://doi.org/10.1016/j.biortech.2005.11.024

Heinonen-Tanski, H., \& Wijk-Sijbesma, V. C. (2005). Human Excreta for Plant Production. Bioresource Technology, 96, 403-411. https://doi.org/10.1016/j.biortech.2003.10.036 
Höglund, C., Stenström, T. A., \& Ashbolt, N. (2002). Microbial Risk Assessment of Source-Separated Urine Used in Agriculture. Waste Management \& Research, 20, 150-161. https://doi.org/10.1177/0734242X0202000207

Jamal, A., \& Fawad, M. (2019). Assessment of Combined Effect of Human Feces Compost and Single Superphosphate on the Behaviour of Wheat Production. Agronomic Research in Moldavia, 52, 220-227. https://doi.org/10.46909/cerce-2019-0022

Levantesi, C., Bonadonna, L., Briancesco, R., Grohmann, E., Toze, S., \& Tandoi, V. (2012). Salmonella in Surface and Drinking Water: Occurrence and Water-Mediated Transmission. Food Research International, 45, 587-602. https://doi.org/10.1016/j.foodres.2011.06.037

Maiga, Y., Ndiaye, A., Sangaré, D., Bitié, E., \& Ushijima, K. (2018). Effect of Slanted Soil Design and Filter Media Distribution on the Removal of Fecal Bacteria and Organic Matter from Greywater. International Journal of Current Microbiology and Applied Sciences, 7, 2317-2329. https://doi.org/10.20546/ijcmas.2018.707.270

Majowicz, S. E., Musto, J., Scallan, E., Angulo, F. J., Kirk, M., O’Brien, S. J., Jones, T. F., Fazil, A., \& Hoekstra, R. M. (2010). The Global Burden of Non Typhoidal Salmonella Gastroenteritis. Clinical Infectious Diseases, 50, 882-889.

https://doi.org/10.1086/650733

Metcalf \& Eddy. (2007). Water Reuse: Issues, Technologies, and Application. M. C. Graw Hill (Ed.), RR Donnelley.

Morel, A., \& Diener, S. (2006). Greywater Management in Low and Middle-Income Countries, Review of Different Treatment Systems for Households and Neighbourhood (No. 14/06, 107 p). Swiss Federal Institute of Aquatic Science and Technology (Eawag).

Petterson, S. R., \& Ashbolt, N. J. (2016). QMRA and Water Safety Management: Review of Application in Drinking Water Systems. Journal of Water and Health, 14, 571-589. https://doi.org/10.2166/wh.2016.262

Rodhe, L., Stintzing, A. R., \& Steineck, S. (2004). Ammonia Emissions after Application of Human Urine to Clay Soil for Barley Growth. Nutrient Cycling in Agroecosystems, 68, 191-198. https://doi.org/10.1023/B:FRES.0000019046.10885.ee

Sampson, A., Owusu-Ansah, E. G. J., Mills-Robertson, F. C., Ayid, I., Abaidoo, R. C., Hald, T., \& Permin, A. (2017). Probabilistic Quantitative Microbial Risk Assessment Model of Farmer Exposure to Cryptosporidium spp. in Irrigation Water within Kumasi Metropolis-Ghana. Microbial Risk Analysis, 6, 1-8.

https://doi.org/10.1016/j.mran.2017.06.001

Sangare, D., Brou, A. L., Sou/Dakoure, M., \& Tagro, P. V. (2021). Urine Treatment by Solar Disinfection for Agriculture Reuse Purpose in a Poor Rural Context: Case of Burkina Faso. Journal of Water, Sanitation and Hygiene for Development, 11, 1-9. https://doi.org/10.2166/washdev.2020.075

Sangare, D., Sawadogo, B., Sou/Dakoure, M., Ouedraogo, M. D., Hijikata, N., Yacouba, H., Coulibaly, L., \& Funamizu, N. (2018). Short Term Effects of Treated Greywater by High Rate Algal Ponds Process on Vegetable Yield and Soil Properties under Sudano-Sahelian Climate Conditions. Environmental Progress \& Sustainable Energy, 37, 465-470. https://doi.org/10.1002/ep.12658

Sangare, D., Sou/Dakoure, M., Hijikata, N., Lahmar, R., Yacouba, H., Coulibaly, L., \& Funamizu, N. (2015). Toilet Compost and Human Urine Used in Agriculture: Fertilizer Value Assessment and Effect on Cultivated Soil Properties. Environmental Technology, 36, 1291-1298. https://doi.org/10.1080/09593330.2014.984774

Schönning, C., Westrell, T., Stenström, T. A., Arnbjerg-Nielsen, K., Hasling, A. B., Høibye, L., \& Carlsen, A. (2007). Microbial Risk Assessment of Local Handling and 
Use of Human Faeces. Journal of Water and Health, 5, 117-128.

https://doi.org/10.2166/wh.2006.049

Shi, K. W., Wang, C. W., \& Jiang, S. C. (2018). Quantitative Microbial Risk Assessment of Greywater On-Site Reuse. Science of the Total Environment, 635, 1507-1519. https://doi.org/10.1016/j.scitotenv.2018.04.197

Shuval, H., Lampert, Y., \& Fattal, B. (1997). Development of a Risk Assessment Approach for Evaluating Wastewater Reuse Standards for Agriculture. Water Science \& Technology, 35, 15-20. https://doi.org/10.2166/wst.1997.0703

Somda, M. K., Samake, S., Kabore, D., Nikiema, M., Mogmenga, I., Dabire, Y., Ouattara, A., Keita, I., Mihin, H. B., Akakpo, A. Y., \& Traore, A. S. (2019). Assessment of Heavy Metals and Microbial Pollution of Lettuce (Lactuca sativa) Cultivated in Two Sites (Paspanga and Tanghin) of Ouagadougou, Burkina Faso. Journal of Environmental Protection, 10, 454-471. https://doi.org/10.4236/jep.2019.103026

Sossou, S. K., Sou/Dakoure, M., Konate, Y., Maiga, A. H., \& Funamizu, N. (2016). Inactivation Kinetics of Indicator Microorganisms during Urea Treatment for Sanitizing finished Compost from Composting Toilet. Journal of Water, Sanitation and Hygiene for Development, 6, 269-275. https://doi.org/10.2166/washdev.2016.090

Stine, S. W., Song, I., Choi, C. Y., \& Gerba, C. P. (2005). Application of Microbial Risk Assessment to the Development of Standards for Enteric Pathogens in Water Used to Irrigate Fresh Produce. Journal of Food Protection, 68, 913-918. https://doi.org/10.2166/washdev.2016.090

Strunz, E. C., Addiss, D. G., Stocks, M. E., Ogden, S., Utzinger, J., \& Freeman, M. C. (2014). Water, Sanitation, Hygiene, and Soil-Transmitted Helminth Infection: A Systematic Review and Meta-Analysis. PLoS Medicine, 11, Article ID: e1001620. https://doi.org/10.1371/journal.pmed.1001620

Tagro, P. (2012). Performance de la Désinfection solaire (SODIS) sur le traitement des urines destinées à l’agriculture. Mémoire de Master. 2iE. https://doi.org/10.1016/j.desal.2008.05.080

Werner, C., Panesar, A., Rüd, S. B., \& Olt, C. U. (2009). Ecological Sanitation: Principles, Technologies and Project Examples for Sustainable Wastewater and Excreta Management. Desalination, 248, 392-401.

Wiel-Shafran, A., Ronen, Z., Weisbrod, N., Adar, E., \& Gross, A. (2006). Potential Changes in Soil Properties Following Irrigation with Surfactant-Rich Greywater. Ecological Engineering, 26, 348-354. https://doi.org/10.1016/j.ecoleng.2005.12.008

World Health Organization (WHO) (2006). Guidelines for the Use of Wastewater Excreta and Greywater: Wastewater Use in Agriculture (Vol. 1, 2, 4). World Health Organization. 